\title{
Studi Parameter Kimia Perairan Pada Kawasan Rencana Pengembangan Tambak Super-Intensif Udang Vaname (Litopenaeus vanamei) di Kabupaten Konawe Selatan
}

\author{
[Study of Water Chemistry Parameters in the Development Plan Area of Super- \\ Intensive Vaname (Litopenaeus vanamei) Pond in South Konawe Regency]
}

\author{
Abdul Muis Balubi ${ }^{1}$, Muhammad Fajar Purnama ${ }^{2}$, LM. Junaidin Sirza ${ }^{3}$, Amadhan \\ Takwir $^{4}$, Disnawati ${ }^{1}$, Trial Fiar Erawan ${ }^{4}$, A. Ginong Pratikino ${ }^{4}$ \\ ${ }^{1}$ Jurusan Budidaya Perairan, Fakultas Perikanan dan Kelautan, Universitas Halu Oleo \\ ${ }^{2}$ Jurusan Manajemen Sumberdaya Perairan, Fakultas Perikanan dan Kelautan, Universitas Halu Oleo \\ ${ }^{3}$ Prodi Pengelolaan Sumberdaya Perairan, Fakultas Pertanian, Universitas Muhammadiyah Buton \\ ${ }^{4}$ Jurusan Ilmu Kelautan, Fakultas Perikanan dan Kelautan, Universitas Halu Oleo \\ ${ }^{1,2,4}$ Jl. H.E.A. Mokodompit Kampus Bumi Tridharma Anduonohu Kendari, Indonesia 93232 \\ ${ }^{3}$ Jl. Betoambari, Lanto, Batupoar, Kota Bau-Bau, Sulawesi Tenggara, Indonesia 93724 \\ Email korespondensi: muhammadfajarpurnama@gmail.com
}

\begin{abstract}
Abstrak
Penelitian ini dilaksanakan selama 4 (empat) bulan, yaitu Oktober 2019 hingga Januari 2020, yang bertempat di perairan pantai dan laut kecamatan Laine dan kecamatan Kolono kabupaten Konawe Selatan. Penelitian ini bertujuan untuk mengetahui kondisi parameter kimia (salinitas, oksigen terlarut (DO) ammonia, nitrogen, phopat, dan bahan organik) pada kawasan rencana pengembangan tambak super-intesif udang vaname (Litopenaeus vanamei). Lokasi pengukuran dan pengambilan sampel secara garis besar dibagi menjadi 4 stasiun yang melintasi perairan 2 kecamatan (Lainea dan Kolono) dengan potensi dan potensial lahan tambak yang tersebar. Setiap stasiun terdiri dari 4 spot pengamatan yang berjumlah 16 spot penelitian. Stasiun I spot 1 dan 2 desa Lainea, spot 3 dan 4 desa Molinese. Stasiun II spot 1, 2, 3, dan 4 semuanya desa Polewali. Stasiun III spot 1, 2, dan 3 desa Molinese, dan spot 4 desa Polewali. Stasiun IV spot 1, 2, 3, dan 4 semuanya terletak di desa Puupi kecamatan Kolono. Pemilihan stasiun dan spot ini setelah dilakukan monitoring sekitar 3 (tiga) bulan merupakan kondisi yang baik untuk kegiatan industri tambak super intensif udang vaname. Kualitas hidrologi perairan laut dengan derajat keasaman 7,44-8,30, oksigen terlarut 4,40-12,7 mg/liter dan kisaran salinitas air laut 31,3-41,3 ppt, masih dalam keadaan layak bagi industri tambak superintensif udang vaname. Kesuburan perairan tambak selama penelitian berupa kosentrasi nitrat $0,0544-$ 0,0881 mg/liter, phospat 0,0053-0,0093 mg/liter, amonia 0,0101-0,0239 mg/liter, dan bahan organik 16,620-27,625 $\mathrm{mg} /$ liter. Konsentrasi parameter kimia perairan pada lokasi penelitian pada dasarnya berada pada kisaran optimal dan layak bagi pengembangan industri tambak superintensif udang vaname.
\end{abstract}

Kata Kunci : Studi Kelayakan, Parameter Kimia, Tambak Super-Intensif, Udang Vaname

\section{Abstract}

This research was carried out for 4 (four) months, namely October 2019 to January 2020, which took place in the waters and seas of Laine sub-district and Kolono sub-district, South Konawe district. This study aims to determine the condition of chemical parameters (salinity, dissolved oxygen, ammonia, nitrogen, phosphate, and organic matter) in the area of the plan to develop super-intensive shrimp ponds (Litopenaeus vanamei). The measurement location and sampling of water chemistry parameters are broadly divided into 4 stations that cross 2 waters (Lainea and Kolono) with the potential and potential of scattered ponds. Each station consists of 4 observation spots totaling 16 research spots. Station I is spot 1 and 2 in Lainea village, spot 3 and 4 in Molinese village. Station II spots 1, 2, 3, and 4 are all Polewali villages. Station III spots 1, 2, and 3 Molinese villages, and spot 4 Polewali villages. Station IV spots 1, 2, 3, and 4 are all located in Puupi village, Kolono sub-district. The selection of stations and spots after monitoring for about 3 (three) months is a good condition for the activities of the super intensive shrimp shrimp industry. The hydrological quality of sea waters with acidity level of 7.44-8.30, dissolved oxygen 4.40-12.7 mg / liter and the range of salinity of sea water 31.3-41.3 ppt, is still in a decent condition for the shrimp superintensive pond industry vaname. Fertility of pond waters during the study was in the form of nitrate concentration $0.0544-0.0881 \mathrm{mg}$ / liter, phosphate 0.0053-0.0093 mg / liter, ammonia 0.0101-0.02239 mg / liter, and organic matter 16.620-27.625 mg /liter. The concentration of aquatic chemical parameters at the research location is basically in the optimal range and feasible for the development of the vaname shrimp superintensive pond industry.

Keywords : Feasibility study, Chemical Parameters, Super-Intensive Pond, Shrimp Vaname 


\section{PENDAHULUAN}

Potensi kelautan dan perikanan Kabupaten Konawe Selatan diharapkan mampu menggerakan perekonomian dan menjadi modal dasar peningkatan pendapatan masyarakat. Perekonomian masyarakat pesisir yang bertumpu pada perikanan tangkap utamanya nelayan tradisional belum mampu mengangkat derajat kehidupan yang memadai. Hasil tangkapan nelayan hanya mampu memenuhi kebutuhan bertahan hidup, belum dapat memenuhi kebutuhan sekunder dan tersier. Kondisi sosial demikian wilayah pesisir laut dan pulaupulau kecil nampak tidak berdaya. Pemukiman di wilayah pesisir laut dan pulau-pulau kecil terlihat mayoritas kumuh, dengan berbagai keterbatasan infrastruktur. Padahal potensi sumberdaya perikanan khususnya budidaya udang dan ikan begitu menjanjikan. Potensi budidaya tambak kabupaten Konawe Selatan 7.652,32 ha, diantaranya kecamatan Lainea seluas 2.741 ha dan kolono 491,55 ha (DKP Kabupaten Konawe Selatan, 2016).

Kabupaten Konawe Selatan adalah salah satu spot pengembangan industri perikanan nasional dengan terdaftar sebagai salah satu daerah minapolitan di Indonesia (KKP RI, 2007). Program minapolitan merupakan terobosan unggulan dalam mewujudkan Indonesia sebagai penghasil produk perikanan terbesar di dunia tahun 2009, namun belum dicapai. Konawe Selatan ditetapkan sebagai daerah minapolitan di Indonesia karena memiliki potensi perikanan yang sangat besar yiatu perikanan tangkap air laut dan ikan air tawar pelagik dan demersal, perikanan budidaya laut, budidaya ikan air tawar, dan budidaya ikan air payau. Target produksi minapolitan khususnya budidaya udang di tambak belum tercapai karena rendah mutu manajemen dan ketidak berpihakan investasi. Informasi tidak masuknya investasi karena data base pengelolaan industri akuakultur sangat minim, kurangnya ketersediaan hasil riset, sumberdaya manusia yang terampil terbatas, dan kurangnya pembiayaan. Investor masih ragu untuk menanamkan modalnya disektor pertambakan udang khususnya udang vaname (Litopenaeus vanamei) karena masalah terbatasnya data base hasil-hasil riset dan tenaga terampil dibidangnya sangat kurang.

Untuk perluasan usaha industri budidaya udang vaname maka diperlukan konsep dasar meliputi potensi pengembangan terutama kebutuhan pasar nasional hingga dunia dan potensi lokasi akuakultur yang memenuhi persyaratan teknis. Untuk pengembangan budidayanya berskala industri besar dan moderen diperlukan tiga dokumen besar yaitu: 1) Dokumen studi potensi pengembangan,

2) Dokumen studi identifikasi, dan 3) Dokumen studi kelayakan atau master plan. Guna implementasi pembangunan industri superintensif budidaya udang vaname ini dibutuhkan desain rinci, pembangunan konstruksi tambak yang kuat, pengawasan pelaksanaan pekerjaan, dan monitoring evaluasi pelaksanaan (DKP Kabupaten Konawe Selatan, 2016).

Desain dan konstruksi tambak, saluran irigasi inlet/outlet, pintu pemasukan dan pengeluaran air merupakan komponen yang tak terpisahkan. Membuat desain pertambakan udang vaname dibutuhkan uraian program kegiatan meliputi : 1) Pemetaan atau peta tematik lokasi kawasan tambak intensif/superintensif, 2) Cara pembuatan model detail desain dan gambar konstruksi tambak, 3) Pencetakan tambak/pembuatan pematang, 4) Pembuatan saluran irigasi primer dan sekunder, 5) Saluran pemasukan dan pengeluaran air tambak. 6) Konstruksi pintu air, 7) Pembangunan jalan produksi dan jalan tani, 8) Pembangunan jembatan melewati muara sungai, dan 9) Pengawasan, monitoring evaluasi tingkat kesuksesan pekerjaan fisik dan non fisik industri budidaya udang vaname ( $L$. Vanamei).

Berdasarkan data kualitas lahan dapat dilakukan pendataan tentang kualitas tanah dan kualitas air untuk mengukur produktivitas lahan tambak. Salah satunya adalah faktor kimia lahan meliputi $\mathrm{pH}$, salinitas, Nitrat, Phospat, oksigen terlarur (DO) dan amonia (NH3). Berdasarkan data DKP kabupaten Konawe Selatan (2016) 
kualitas lahan tambak suhu perairan tertinggi $33^{\circ} \mathrm{C}$ terendah $27^{\circ} \mathrm{C}$. Tekstur tanah tambak mayoritas lempung debu (lahan gambut), derajat keasaman $(\mathrm{pH})$ rata-rata 6 , karena masih terlalu banyak sisa pelapukan organik. Kandungan nitrat tanah tambak berkisar antara 0,0277-0,0500 $\mathrm{mg} / \mathrm{l}$. Kandungan Phospat perairan tambak berkisar antara 0,0032-0,0217 $\mathrm{mg} / \mathrm{l}$. Oksigen terlarut berkisar 5,4-6,85 $\mathrm{mg} / \mathrm{l}$ atau 5,4-6,85 ppm.

Data-data diatas masih kurang jika untuk menentukan perencanaan pembangunan tambak tambak intensif dalam waktu jangka panjang. Oleh karena itu penelitian mengenai studi parameter kimia perairan pada kawasan rencana pengembangan tambak super-intensif udang vaname (Litopenaeus vanamei) di Kabupaten Konawe Selatan sangat penting untuk dilakukan, mengingat informasi kesuburan lahan tambak merupakan salah satu petunjuk dasar dalam menentukan arah perencanaan dan layout pembangunan industri tambak udang vaname serta sebagai informasi awal yang dapat dijadikan acuan dalam menentukan keputusan kelayakan dan metode aplikasi kegiatan pertambakan udang vaname.

\section{BAHAN DAN METODE}

Penelitian ini dilaksanakan selama 4 (empat) bulan, yaitu Oktober 2019 hingga Januari 2020, yang bertempat di perairan pantai dan laut kecamatan Laine dan kecamatan Kolono kabupaten Konawe Selatan. Lokasi penelitian perairan laut yang secara langsung berhubungan dengan sumber air irigasi tambak udang vaname dan ikan bandeng di wilayah pesisir lokasi penelitian. Lokasi dan spot penelitian disajikan pada peta Gambar 2.

\section{Penentuan Stasiun Penelitian}

Lokasi penelitian secara garis besar dibagi menjadi 4 stasiun yang melintasi perairan 2 kecamatan (Lainea dan Kolono) dengan potensi dan potensial lahan tambak yang terbesar. Setiap stasiun terdiri dari 4 spot pengamatan yang berjumlah 16 spot penelitian. Stasiun I spot 1 dan 2 desa
Lainea, spot 3 dan 4 desa Molinese. Stasiun II spot 1, 2, 3, dan 4 semuanya desa Polewali. Stasiun III spot 1, 2, dan 3 desa Molinese, dan spot 4 desa Polewali. Stasiun IV apot 1, 2, 3, dan 4 semuanya terletak di desa Puupi kecamatan Kolono. Pemilihan stasiun dan spot ini setelah dilakukan monitoring sekitar 3 bulan merupakan kondisi yang baik untuk kegiatan industri tambak super intensiv udang vaname.

\section{Pengukuran Parameter Kimia}

Pengukuran kualitas air disetiap lokasi dilakukan secara insitu dan eksitu. Pengukuran parameter lingkungan yang dilakukan secara insitu meliputi pengukuran salinitas menggunakan refraktometer, $\mathrm{pH}$ menggunakan $\mathrm{pH}$ meter, dan Oksigen terlarut (DO) menggunakan DO meter. Pengukuran DO, pengukuran salinitas menggunakan refraktometer, pengukuran $\mathrm{pH}$.

Analisis kandungan ammonia, nitrogen, phopat, dan bahan organik dilakukan secara eksitu. Pengambilan sampel air dilakukan dengan cara memasukkan sampel air ke dalam botol sampel sebanyak $1500 \mathrm{ml}$. Sampel air di ambil dari permukaan air sampai kira- kira setengah kedalaman hingga penuh, diusahakan jangan ada gelembung udara yang masuk kemudian botol sampel ditutup, diberi label dan dimasukkan ke dalam coolbox lalu dibawa ke laboratorium Produktivitas Lingkungan FPIK, Universitas Halu Oleo Kota Kendari untuk di analisis kandungan ammonia, nitrogen, phopat, dan bahan organik. Metode analisa yang digunakan yaitu SNI 19-7119.1-2005 (Amonia $\left(\mathrm{NH}_{3}-\mathrm{N}\right)$, SNI 06-6989.31:2005 (Posfat), SNI 6989.79:2011 (Nitrat $\left(\mathrm{NO}_{3}{ }^{-}\right.$ N), dan SNI 06 - 6989. 22 - 2004 (Total bahan organik).

Sampel air diambil dari tambak rakyat yang sedang running. Titik pengambilan sampel atau Spot sampling tersebut disajikan pada peta lokasi dengan spot warna merah muda pada Gambar 3. 


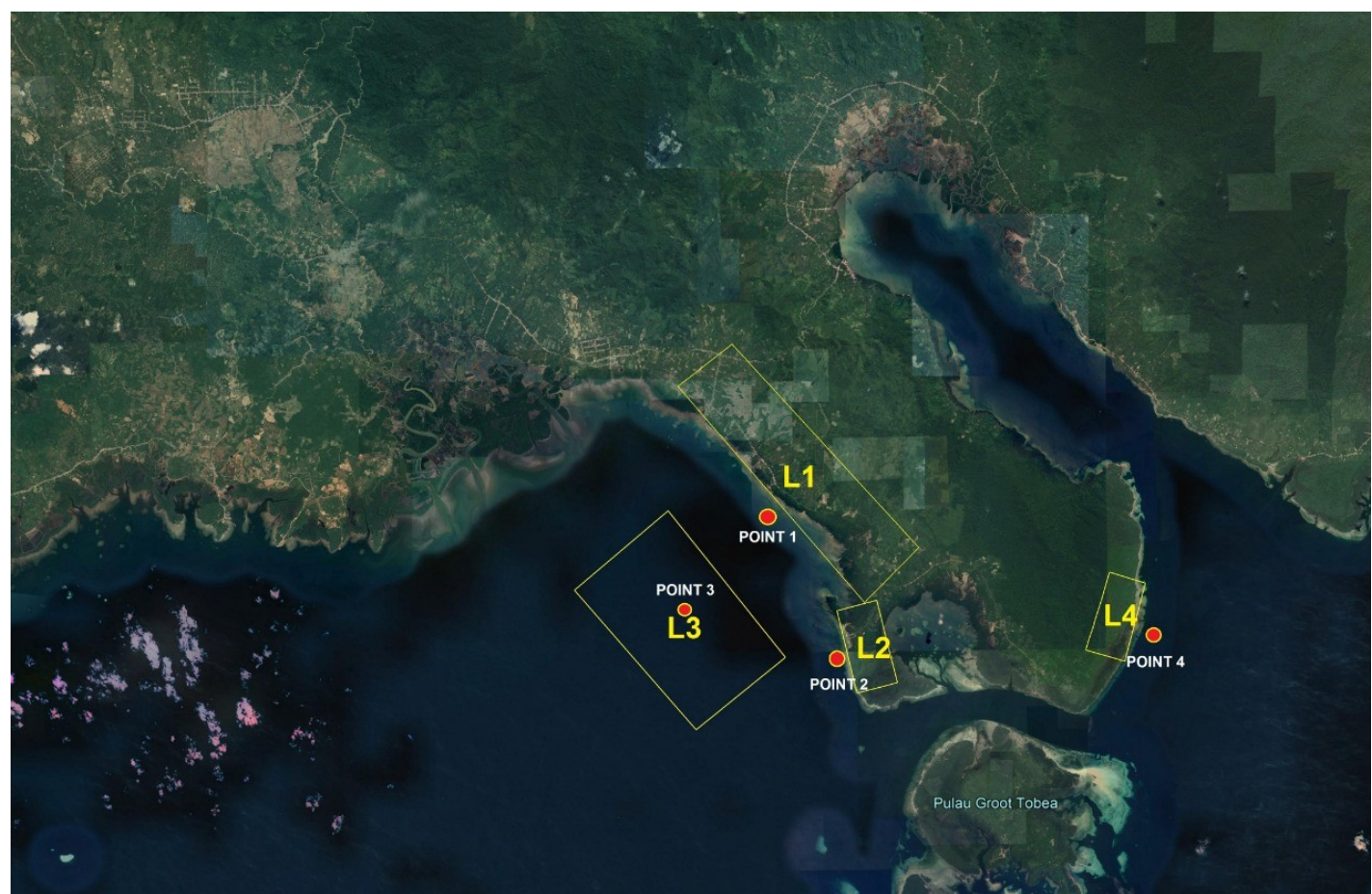

Gambar 2. Peta lokasi penelitian L1 perairan desa Lainea, Molinese, L2 desa Polewali, L3 desa Molinese, Polewali, dan L4 desa Puupi kecamatan Kolono

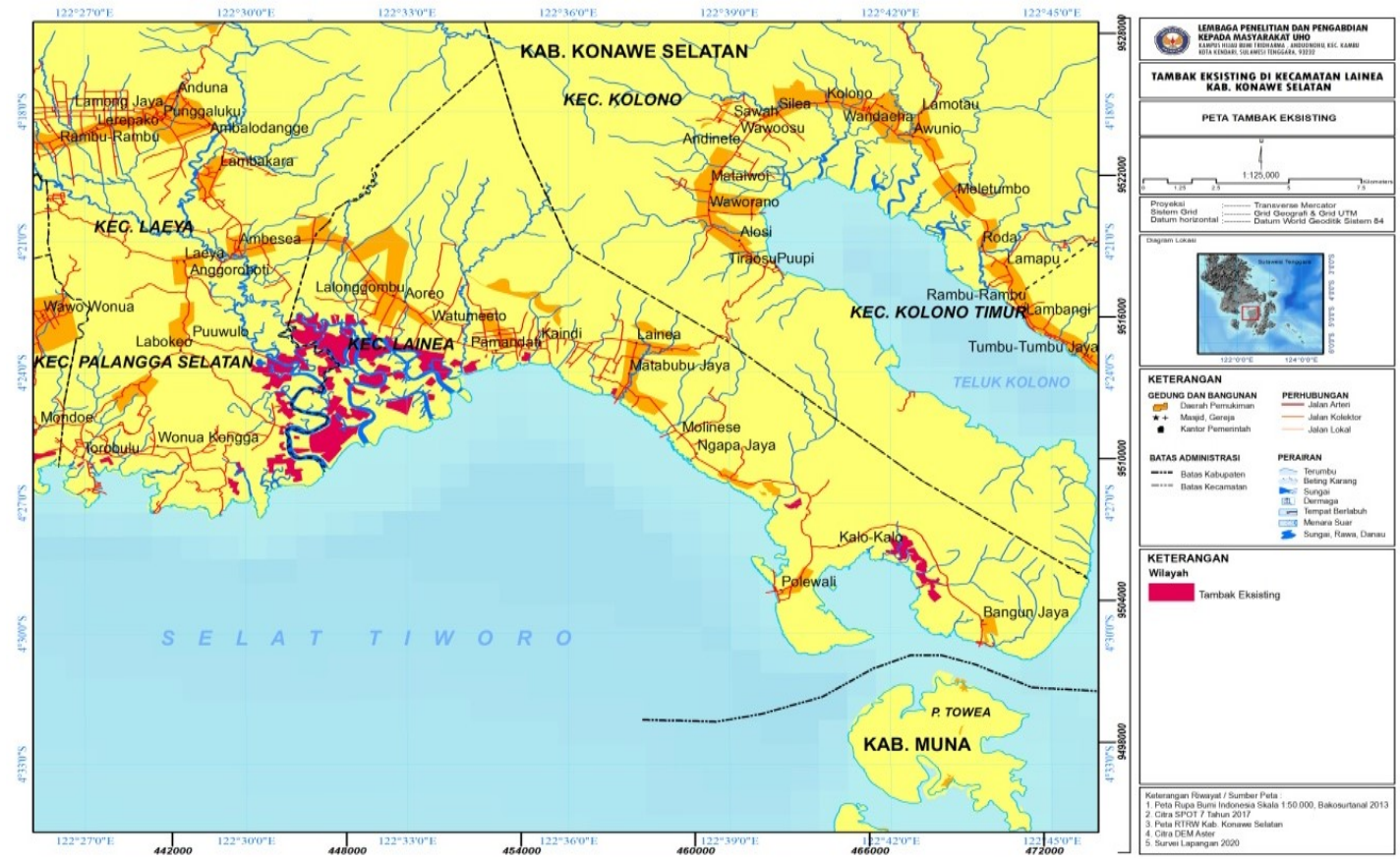

Gambar 3. Lokasi tambak eksisting (pengukuran nitrat, amonia, phospat dan BO air). 


\section{HASIL}

\section{Kualitas Air Perairan}

Hasil pengukuran beberapa paremeter kualitas perairan $(\mathrm{pH}$, Oksigen Terlarut, Suhu, dan Salinitas) yang dilakukan pada Tahap 1 sampai 4 disajikan pada Tabel 1 sampai 4.

\section{Kosentarsi Nitrat (NO3-N), Phospat, Amonia (NH3-N) dan Bahan Organik}

Zat hara yang banyak kalangan fokus pada lingkungan perairan khususnya perairan tambak adalah nitrat, phospat, amonia dan bahan organik. Khusus nitrat dan phospat memiliki peran bagi pertumbuhan phitoplankton atau alga yang biasa digunakan sebagai indikator kualitas air dan tingkat kesuburan suatu perairan. NH3-N merupakan racun yang harus diatasi untuk menghindari kematian udang vaname secara masal. Bahan organik air tambak merupakan petunjuk ketersediaan nutrien yang dapat diserap oleh tumbuhan air. Data hasil pengamatan nitrat (NO3-N), phospat, amonia $(\mathrm{NH} 3-\mathrm{N})$ dan bahan organik (BO) air tambak Kecamatan Lainea Kabupaten Konawe Selatan selama penelitian disajikan pada Gambar 4, 6 dan 7 .

Kosentrasi nitrat tertinggi ada di spot D desa Lalonggombu sebesar $0,1017 \mathrm{mg} /$ liter. Secara berturut-turut selanjutnya diikuti oleh spot A (Barat Lalonggombu) sebesar 0,1012 mg/ liter, spot B (Selatan Lalonggombu) sebesar $0,0964 \mathrm{mg} /$ liter, dan spot E (Timur Lalonggombu) sebesar 0,0944 $\mathrm{mg} /$ liter. Kandungan nitrat terendah ada di spot C (Selatan Puupi) sebesar $0,0774 \mathrm{mg} /$ liter (Gambar 4).

Kandungan phospat tertinggi terdapat di spot E (Timur Lalonggombu) sebesar $0,0093 \mathrm{mg} /$ liter. Kemudian secara berurutan kandungan phospat spot C (selatan Puupi) sebesar $0,0085 \mathrm{mg} /$ liter, spot B sebesar $0,0069 \mathrm{mg} /$ liter, spot A sebesar $0,0068 \mathrm{mg} /$ liter, dan terendah spot D sebesar 0,0053 $\mathrm{mg}$ / liter (Gambar 4).

Kosentrasi amonia (NH3-N) tertinggi ada di spot A sebesar $0,0239 \mathrm{mg} /$ liter. Kosentrasi amonia selanjutnya secara berurutan spot B sebesar $0,0200 \mathrm{mg} /$ liter, spot D sebesar $0,0182 \mathrm{mg} /$ liter, spot C sebesar 0,0111 , dan terendah spot $\mathrm{E}$ sebesar $0,0101 \mathrm{mg} /$ liter air tambak.

Kosentrasi bahan organik tertinggi terdapat di spot B (Selatan Lalonggombu) sebesar 27,625 mg/ liter. Secara berturutturut diikuti spot E sebesar $22,305 \mathrm{mg} /$ liter, spot A sebesar $21,80 \mathrm{mg} /$ liter, spot C sebesar 19,82 $\mathrm{mg} /$ liter, dan terendah di stasiun D (desa Lalonggombu) sebesar $16,62 \mathrm{mg} /$ liter (Gambar 4).

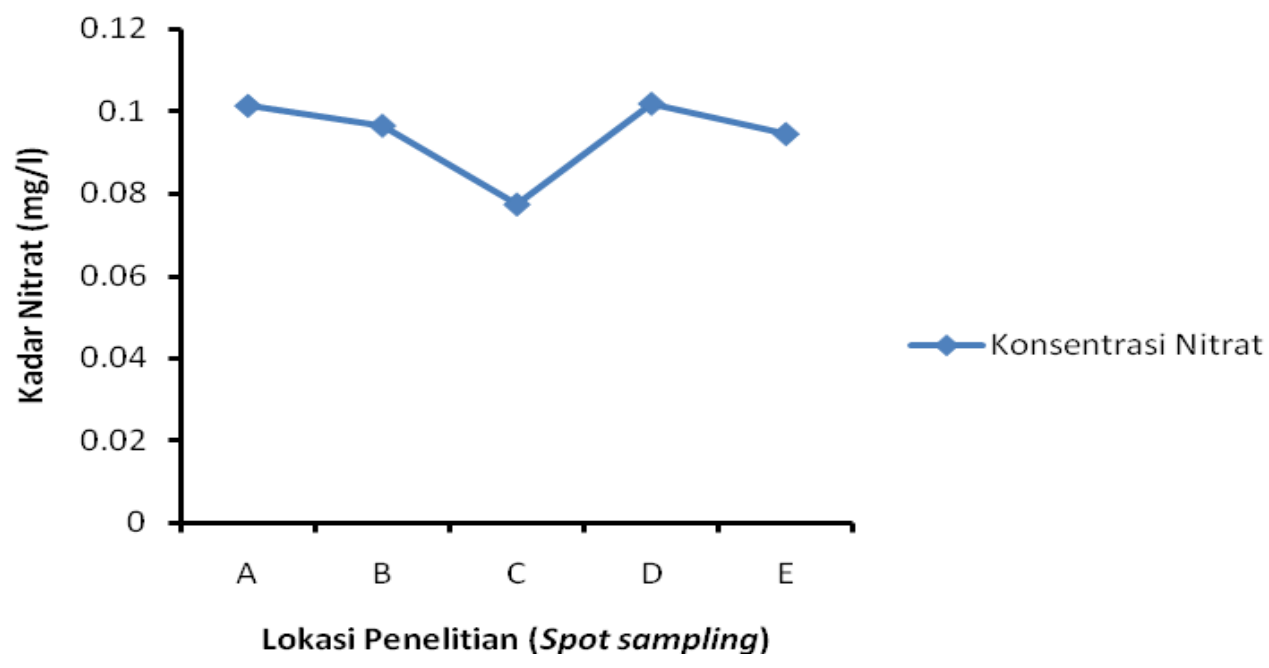

Gambar 4. Grafik kosentrasi Nitrat air tambak desa Lalonggombu dan desa Puupi Kabupaten Konawe Selatan 


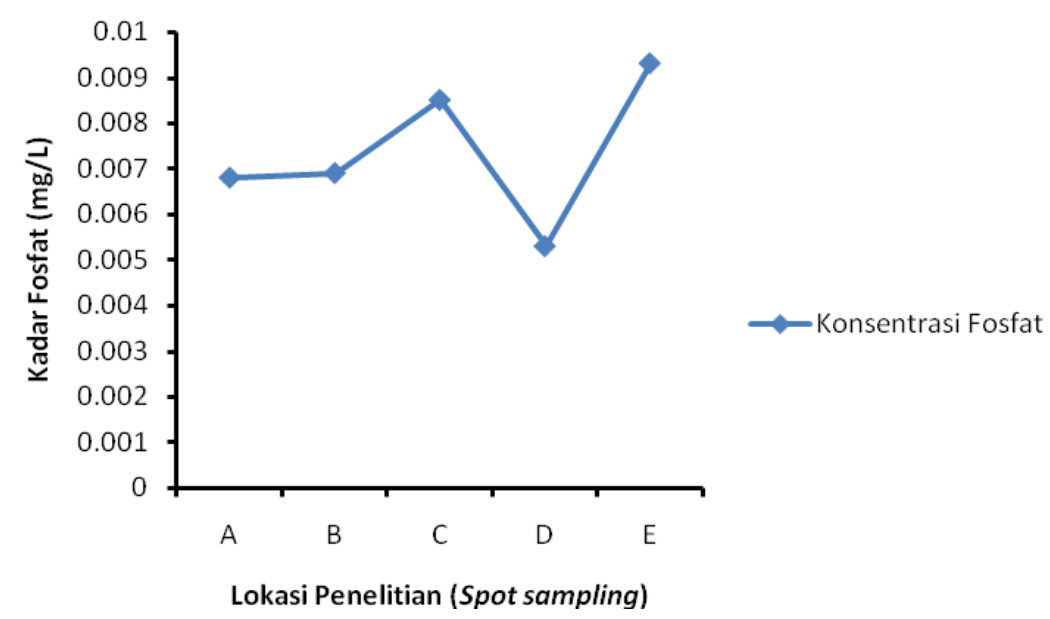

Gambar 5. Grafik kosentrasi Phospat air tambak desa Lalonggombu dan desa Puupi Kabupaten Konawe Selatan

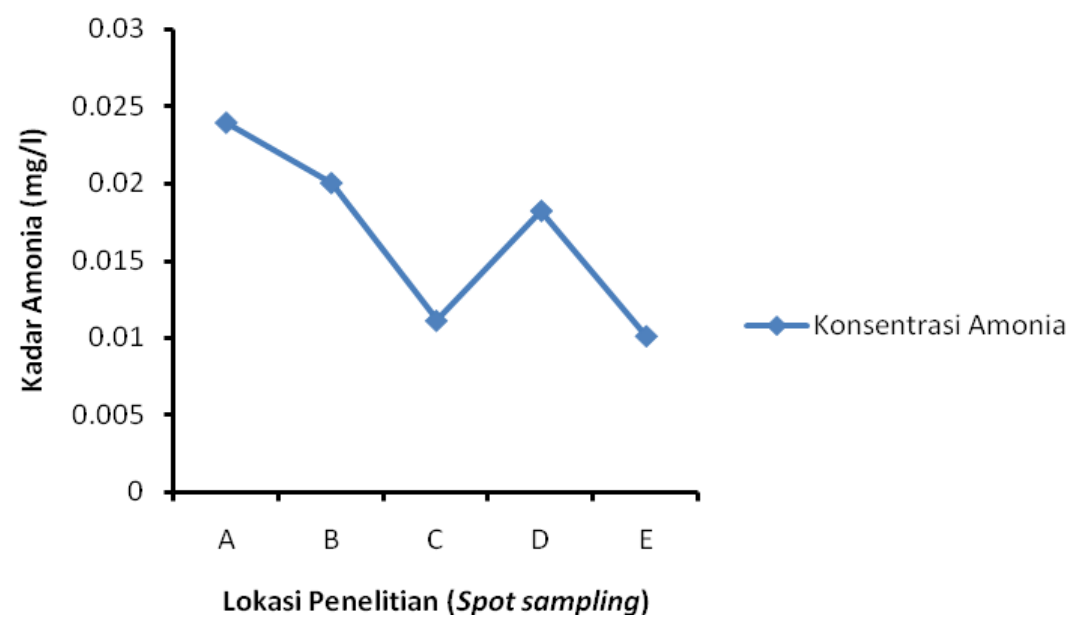

Gambar 6. Grafik kosentrasi Amonia $\left(\mathrm{NH}_{3}-\mathrm{N}\right)$ air tambak desa Lalonggombu dan desa Puupi Kabupaten Konawe Selatan

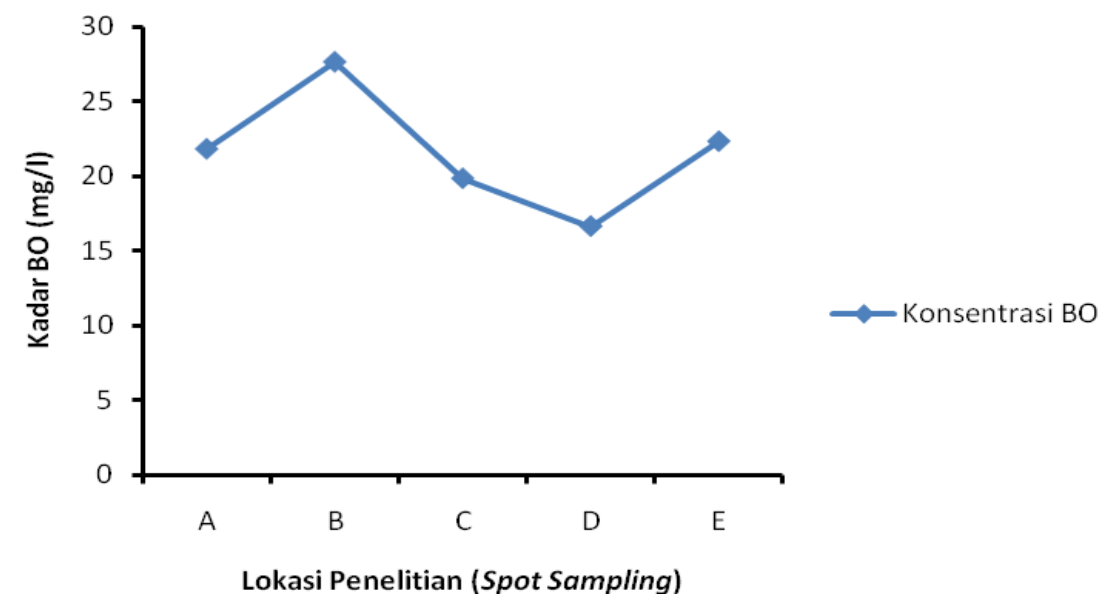

Gambar 7. Grafik kosentrasi Bahan Organik (BO) air tambak desa Lalonggombu dan desa Puupi Kabupaten Konawe Selatan 
Media Akuatika : Jurnal Ilmiah Jurusan Budidaya Perairan. 2020. 5(3): 115-128.

Tabel 1. Data hasil pengukuran $\mathrm{pH}$, Oksigen Terlarut, Suhu, dan Salinitas Tahap 1

\begin{tabular}{|c|c|c|c|c|c|c|c|c|}
\hline \multirow{2}{*}{ St. } & \multirow{2}{*}{ Plot } & \multicolumn{2}{|c|}{ Koordinat } & \multirow{2}{*}{ pH } & \multirow{2}{*}{$\begin{array}{c}\text { DO } \\
(\mathrm{mg} / \mathrm{l})\end{array}$} & \multirow{2}{*}{$\begin{array}{l}\text { Suhu } \\
{ }^{\circ} \mathrm{C}\end{array}$} & \multirow{2}{*}{$\begin{array}{l}\text { Salinitas } \\
\text { (ppt) }\end{array}$} & \multirow{2}{*}{$\begin{array}{c}\text { Waktu } \\
\text { (WITA) }\end{array}$} \\
\hline & & Bujur & Lintang & & & & & \\
\hline I & 1 & 122,61288 & $-4,421777$ & 7,86 & 9,6 & 31,2 & 38,5 & 14,49 \\
\hline I & 2 & 122,627087 & $-4,432704$ & 8,12 & 9,5 & 30,6 & 37,4 & 15,03 \\
\hline I & 3 & 122,635186 & $-4,449414$ & 7,92 & 10,12 & 31,2 & 35,2 & $18: 28$ \\
\hline I & 4 & 122,647119 & $-4,454135$ & 7,60 & 11,2 & 29,5 & 35,1 & $18: 37$ \\
\hline \multicolumn{4}{|c|}{ Rata-Rata } & 7,90 & 10,11 & 30,6 & 35,6 & - \\
\hline II & 1 & 122,65953 & $-4,480827$ & 7,55 & 10,3 & 31,2 & 34,5 & 18:48 \\
\hline II & 2 & 122,660786 & $-4,486577$ & 7,42 & 9,6 & 31,5 & 34,5 & 19:00 \\
\hline II & 3 & 122,663042 & $-4,49253$ & 7,24 & 9,6 & 29,5 & 33,8 & 19:15 \\
\hline II & 4 & 122,663052 & $-4,496799$ & 7,55 & 10,2 & 29,5 & 35,3 & 19:29 \\
\hline \multicolumn{4}{|c|}{ Rata-Rata } & 7,44 & 9,9 & 30,4 & 34,5 & - \\
\hline III & 1 & 122,611754 & $-4,451262$ & 8,08 & 10,16 & 30,9 & 34,15 & $15: 23$ \\
\hline III & 2 & 122,607228 & $-4,463967$ & 7,15 & 10,1 & 30,9 & 34,5 & $15: 36$ \\
\hline III & 1 & 122,65953 & $-4,480827$ & 7,22 & 9,85 & 30,9 & 34,5 & 16:00 \\
\hline III & 2 & 122,660786 & $-4,486577$ & 7,34 & 10,22 & 30,9 & 34,5 & 16:11 \\
\hline \multicolumn{4}{|c|}{ Rata-Rata } & 7,45 & 10,1 & 30,9 & 34,4 & - \\
\hline IV & 1 & 122,761828 & $-4,484713$ & 8,11 & 9,4 & 30 & 35,2 & $16: 58$ \\
\hline IV & 2 & 122,764606 & $-4,482262$ & 7,98 & 9,4 & 30 & 35,4 & $17: 07$ \\
\hline IV & 3 & 122,769797 & $-4,476427$ & 7,88 & 9,6 & 30 & 35 & $17: 16$ \\
\hline IV & 4 & 122,767034 & $-4,470642$ & 7,76 & 9,4 & 30 & 34,8 & $17: 26$ \\
\hline \multicolumn{4}{|c|}{ Rata-Rata } & 7,9 & 9,5 & 30 & 35,1 & - \\
\hline I & 1 & 122,61288 & $-4,421777$ & 7,66 & 10,2 & 30,3 & 34,2 & $10: 25$ \\
\hline I & 2 & 122,627087 & $-4,432704$ & 7,81 & 9,8 & 30,2 & 33,6 & $10: 36$ \\
\hline I & 3 & 122,635186 & $-4,449414$ & 7,88 & 10,2 & 30,6 & 34,40 & $7: 52$ \\
\hline I & 4 & 122,647119 & $-4,454135$ & 7,53 & 8,8 & 30,0 & 34,10 & 8:06 \\
\hline \multicolumn{4}{|c|}{ Rata-Rata } & 7,72 & 9,8 & 30,3 & 34,1 & - \\
\hline II & 1 & 122,65953 & $-4,480827$ & 8,14 & 9,4 & 30,5 & 34,0 & $9: 35$ \\
\hline II & 2 & 122,660786 & $-4,486577$ & 8,14 & 9,6 & 30,2 & 33,2 & 10:05 \\
\hline II & 3 & 122,663042 & $-4,49253$ & 7,46 & 10,5 & 30,4 & 33,2 & $9: 14$ \\
\hline II & 4 & 122,663052 & $-4,496799$ & 7,46 & 9,8 & 30,3 & 32,8 & $9: 24$ \\
\hline \multicolumn{4}{|c|}{ Rata-Rata } & 7,8 & 9,8 & 30,4 & 33,3 & - \\
\hline III & 1 & 122,611754 & $-4,451262$ & 7,8 & 10,4 & 30,4 & 33,6 & $10: 53$ \\
\hline III & 2 & 122,607228 & $-4,463967$ & 7,8 & 10,4 & 30,6 & 40,0 & 11:04 \\
\hline III & 3 & 122,620627 & $-4,468827$ & 8,2 & 9,6 & 30,1 & 33,4 & $8: 24$ \\
\hline III & 4 & 122,622415 & $-4,479393$ & 8,2 & 9,6 & 30,3 & 33,4 & $8: 49$ \\
\hline \multicolumn{4}{|c|}{ Rata-Rata } & 8,0 & 10,0 & 30,4 & 35,1 & - \\
\hline IV & 1 & 122,772881 & $-4,493261$ & 7,5 & 9,8 & 30,4 & 33 & $12 ; 15$ \\
\hline IV & 2 & 122,775308 & $-4,486902$ & 7,6 & 9,8 & 30,4 & 33 & $12 ; 26$ \\
\hline IV & 3 & 122,776698 & $-4,479393$ & 7,8 & 11,0 & 30,4 & 32,5 & $12 ; 39$ \\
\hline IV & 4 & 122,777142 & $-4,471613$ & 7,6 & 10,4 & 30,5 & 32,2 & $12 ; 55$ \\
\hline \multicolumn{4}{|c|}{ Rata-Rata } & 7,6 & 10,3 & 30,4 & 41,1 & - \\
\hline
\end{tabular}


Media Akuatika : Jurnal Ilmiah Jurusan Budidaya Perairan. 2020. 5(3): 115-128.

Tabel 2. Data hasil pengukuran $\mathrm{pH}$, Oksigen Terlarut, Suhu, dan Salinitas Tahap 2

\begin{tabular}{|c|c|c|c|c|c|c|c|c|}
\hline \multirow{2}{*}{ St. } & \multirow{2}{*}{ Plot } & \multicolumn{2}{|c|}{ Koordinat } & \multirow{2}{*}{ pH } & \multirow{2}{*}{$\begin{array}{c}\text { DO } \\
(\mathrm{mg} / \mathrm{l})\end{array}$} & \multirow{2}{*}{$\begin{array}{c}\text { Suhu } \\
{ }^{0} \mathrm{C}\end{array}$} & \multirow{2}{*}{$\begin{array}{c}\text { Salinitas } \\
\text { (ppt) }\end{array}$} & \multirow{2}{*}{ Waktu (WITA) } \\
\hline & & Bujur & Lintang & & & & & \\
\hline I & 1 & 122,61288 & $-4,421777$ & 8,00 & 9,8 & 30,0 & 36,2 & $16: 00$ \\
\hline I & 2 & 122,62709 & $-4,432704$ & 8,12 & 9,5 & 30,0 & 36,0 & $16: 25$ \\
\hline I & 3 & 122,63519 & $-4,449414$ & 7,45 & 10,6 & 30,4 & 35,0 & $16: 50$ \\
\hline I & 4 & 122,64712 & $-4,454135$ & 7,60 & 11,2 & 30,5 & 35,0 & $17: 15$ \\
\hline \multicolumn{4}{|c|}{ Rata-Rata } & 7,86 & 10,3 & 30,2 & 35,6 & - \\
\hline II & 1 & 122,65953 & $-4,480827$ & 7,55 & 11,0 & 31,0 & 34,7 & $17: 35$ \\
\hline II & 2 & 122,66079 & $-4,486577$ & 7,42 & 11,0 & 31,0 & 34,5 & $18: 00$ \\
\hline II & 3 & 122,66304 & $-4,49253$ & 7,24 & 10,2 & 30,0 & 33,8 & $18: 05$ \\
\hline II & 4 & 122,66305 & $-4,496799$ & 7,51 & 11,0 & 30,0 & 35,0 & $18: 15$ \\
\hline \multicolumn{4}{|c|}{ Rata-Rata } & 7,36 & 10,8 & 30,5 & 34,5 & - \\
\hline III & 1 & 122,61175 & $-4,451262$ & 8,00 & 11,0 & 31,0 & 34,0 & $19: 12$ \\
\hline III & 2 & 122,60723 & $-4,463967$ & 8,00 & 11,0 & 31,0 & 34,0 & $19: 26$ \\
\hline III & 3 & 122,62063 & $-4,468827$ & 7,66 & 10,7 & 30,4 & 34,0 & $19: 38$ \\
\hline III & 4 & 122,62242 & $-4,479393$ & 7,34 & 10,5 & 30,9 & 34,0 & 20:05 \\
\hline \multicolumn{4}{|c|}{ Rata-Rata } & 7,75 & 10,8 & 30,8 & 34,0 & - \\
\hline IV & 1 & 122,76183 & $-4,484713$ & 7,14 & 11 & 31,4 & 36,0 & 21:19 \\
\hline IV & 2 & 122,76461 & $-4,482262$ & 7,86 & 10,2 & 31,0 & 35,4 & $21: 28$ \\
\hline IV & 3 & 122,7698 & $-4,476427$ & 7,75 & 9,6 & 31,2 & 35,0 & $21: 38$ \\
\hline IV & 4 & 122,76703 & $-4,470642$ & 7,74 & 9,5 & 31,2 & 36,5 & $21: 53$ \\
\hline \multicolumn{4}{|c|}{ Rata-Rata } & 7,6 & 10,08 & 31,2 & 35,7 & - \\
\hline I & 1 & 122,61288 & $-4,421777$ & 7,55 & 11,0 & 30,0 & 34,0 & $5: 49$ \\
\hline $\mathrm{I}$ & 2 & 122,62709 & $-4,432704$ & 7,98 & 11,0 & 30,0 & 34,2 & $6: 02$ \\
\hline I & 3 & 122,63519 & $-4,449414$ & 7,98 & 10,7 & 30,0 & 34,20 & $6: 20$ \\
\hline $\mathrm{I}$ & 4 & 122,64712 & $-4,454135$ & 7,89 & 10,4 & 30,0 & 34,12 & $6: 35$ \\
\hline \multicolumn{4}{|c|}{ Rata-Rata } & 7,85 & 10,8 & 30,0 & 34,1 & - \\
\hline II & 1 & 122,65953 & $-4,480827$ & 8,14 & 10 & 30,0 & 34,0 & $6: 54$ \\
\hline II & 2 & 122,66079 & $-4,486577$ & 8,12 & 9,6 & 30,0 & 33,0 & 7:04 \\
\hline II & 3 & 122,66304 & $-4,49253$ & 7,55 & 10,2 & 30,0 & 33,2 & $7: 20$ \\
\hline II & 4 & 122,66305 & $-4,496799$ & 7,56 & 10,4 & 30,0 & 33,0 & $7: 37$ \\
\hline \multicolumn{4}{|c|}{ Rata-Rata } & 7,8 & 10,01 & 30,0 & 33,3 & - \\
\hline IV & 1 & 122,76183 & $-4,484713$ & 8,0 & 9,3 & 30,6 & 34,0 & 9:00 \\
\hline IV & 2 & 122,76461 & $-4,482262$ & 8,0 & 9,3 & 30,9 & 34,0 & $9: 20$ \\
\hline IV & 3 & 122,7698 & $-4,476427$ & 8,0 & 9,5 & 30,6 & 34,0 & $9: 50$ \\
\hline IV & 4 & 122,76703 & $-4,470642$ & 8,2 & 9,6 & 30,5 & 33,0 & $10: 15$ \\
\hline \multicolumn{4}{|c|}{ Rata-Rata } & 8,0 & 9,4 & 30,65 & 33,7 & - \\
\hline III & 1 & 122,61175 & $-4,451262$ & 7,6 & 10,0 & 30,4 & 33,4 & $14: 29$ \\
\hline III & 2 & 122,60723 & $-4,463967$ & 7,8 & 10,0 & 30,4 & 33,5 & $14: 57$ \\
\hline III & 3 & 122,62063 & $-4,468827$ & 7,8 & 11,0 & 30,4 & 33,3 & $15: 10$ \\
\hline III & 4 & 122,62242 & $-4,479393$ & 7,8 & 10,5 & 30,5 & 33,2 & $15: 24$ \\
\hline \multicolumn{4}{|c|}{ Rata-Rata } & 7,7 & 10,4 & 30,4 & 33,4 & - \\
\hline
\end{tabular}


Media Akuatika : Jurnal Ilmiah Jurusan Budidaya Perairan. 2020. 5(3): 115-128.

Tabel 3. Data hasil pengukuran $\mathrm{pH}$, Oksigen Terlarut, Suhu, dan Salinitas Tahap 3

\begin{tabular}{|c|c|c|c|c|c|c|c|c|}
\hline \multirow{2}{*}{ St. } & \multirow{2}{*}{ Plot } & \multicolumn{2}{|c|}{ Koordinat } & \multirow{2}{*}{$\begin{array}{c}\text { pH } \\
\text { (ppt) }\end{array}$} & \multirow{2}{*}{$\begin{array}{c}\text { DO } \\
(\mathrm{mg} / \mathrm{l})\end{array}$} & \multirow{2}{*}{$\begin{array}{c}\text { Salinitas } \\
\text { (ppt) }\end{array}$} & \multirow{2}{*}{$\begin{array}{l}\text { Suhu } \\
\left({ }^{\circ} \mathrm{C}\right)\end{array}$} & \multirow{2}{*}{$\begin{array}{l}\text { Waktu } \\
\text { (WITA) }\end{array}$} \\
\hline & & Bujur & Lintang & & & & & \\
\hline I & 1 & 122,61288 & $-4,421777$ & 8,15 & 9,3 & 41,0 & 31,1 & $15: 39$ \\
\hline I & 2 & 122,627087 & $-4,432704$ & 8,19 & 10,6 & 40,9 & 30,6 & $15: 57$ \\
\hline $\mathrm{I}$ & 3 & 122,635186 & $-4,449414$ & 8,17 & 12,5 & 40,9 & 30,4 & 16:09 \\
\hline I & 4 & 122,647119 & $-4,454135$ & 8,20 & 12,0 & 40,9 & 30,3 & $16: 24$ \\
\hline \multicolumn{4}{|c|}{ Rata-Rata } & 8,2 & 11,1 & 40,9 & 30,6 & - \\
\hline II & 1 & 122,65953 & $-4,480827$ & 8,25 & 11,3 & 41,0 & 30,2 & $16: 42$ \\
\hline II & 2 & 122,660786 & $-4,486577$ & 8,20 & 12,4 & 41,0 & 30,7 & 16:53 \\
\hline II & 3 & 122,663042 & $-4,49253$ & 8,19 & 13,4 & 40,9 & 30,2 & $17: 04$ \\
\hline II & 4 & 122,663052 & $-4,496799$ & 8,11 & 12,2 & 41,0 & 30,1 & $17: 16$ \\
\hline \multicolumn{4}{|c|}{ Rata-Rata } & 8,2 & 12,3 & 41,0 & 30,3 & - \\
\hline III & 1 & 122,611754 & $-4,451262$ & 8,05 & 13,1 & 40,2 & 31,2 & 13:19 \\
\hline III & 2 & 122,607228 & $-4,463967$ & 8,01 & 12,23 & 40,3 & 31,5 & $13: 33$ \\
\hline III & 3 & 122,620627 & $-4,468827$ & 8,17 & 12,14 & 41,1 & 31,2 & $13: 50$ \\
\hline III & 4 & 122,622415 & $-4,479393$ & 8,20 & 13,22 & 41,1 & 31,3 & 14:00 \\
\hline \multicolumn{4}{|c|}{ Rata-Rata } & 8,1 & 12,7 & 40,7 & 31,3 & - \\
\hline IV & 1 & 122,761828 & $-4,484713$ & 8,35 & 15,0 & 41,0 & 31,7 & 14:23 \\
\hline IV & 2 & 122,764606 & $-4,482262$ & 8,17 & 12,3 & 40,9 & 31,4 & $14: 37$ \\
\hline IV & 3 & 122,769797 & $-4,476427$ & 8,03 & 6,6 & 41,0 & 31,4 & $15: 02$ \\
\hline IV & 4 & 122,767034 & $-4,470642$ & 8,05 & 6,8 & 41,1 & 31,2 & $15: 15$ \\
\hline \multicolumn{4}{|c|}{ Rata-Rata } & 8,2 & 10,2 & 41,0 & 31,4 & - \\
\hline I & 1 & 122,61288 & $-4,421777$ & 8,0 & 4,5 & 41,0 & 30,3 & $10: 59$ \\
\hline I & 2 & 122,627087 & $-4,432704$ & 8,09 & 5,1 & 41,0 & 29,9 & $10: 49$ \\
\hline $\mathrm{I}$ & 3 & 122,635186 & $-4,449414$ & 8,15 & 5,5 & 41,0 & 29,8 & $10: 36$ \\
\hline $\mathrm{I}$ & 4 & 122,647119 & $-4,454135$ & 8,26 & 6,5 & 41,0 & 29,9 & $10: 22$ \\
\hline \multicolumn{4}{|c|}{ Rata-Rata } & 8,2 & 21,5 & 41,0 & 30,0 & - \\
\hline II & 1 & 122,65953 & $-4,480827$ & 8,27 & 6,6 & 41,0 & 29,8 & 10:09 \\
\hline II & 2 & 122,660786 & $-4,486577$ & 8,26 & 6,8 & 41,0 & 30,0 & $9: 59$ \\
\hline II & 3 & 122,663042 & $-4,49253$ & 8,25 & 7,4 & 41,0 & 29,9 & $9: 51$ \\
\hline II & 4 & 122,663052 & $-4,496799$ & 8,26 & 7,1 & 41,0 & 29,9 & $9: 44$ \\
\hline \multicolumn{4}{|c|}{ Rata-Rata } & 8,3 & 7,0 & 41,0 & 29,9 & - \\
\hline III & 1 & 122,611754 & $-4,451262$ & 8,25 & 11,5 & 41,0 & 30,1 & $8: 44$ \\
\hline III & 2 & 122,607228 & $-4,463967$ & 8,25 & 12,6 & 41,1 & 30,4 & $8: 55$ \\
\hline III & 3 & 122,620627 & $-4,468827$ & 8,28 & 12,6 & 41,1 & 30,3 & 9:08 \\
\hline III & 4 & 122,622415 & $-4,479393$ & 8,32 & 10,1 & 41,2 & 30,3 & $9: 20$ \\
\hline \multicolumn{4}{|c|}{ Rata-Rata } & 8,3 & 11,7 & 41,1 & 30,3 & - \\
\hline IV & 1 & 122,761828 & $-4,484713$ & 8,21 & 4,3 & 41,2 & 30,3 & $11: 39$ \\
\hline IV & 2 & 122,764606 & $-4,482262$ & 8,20 & 4,4 & 41,4 & 30,7 & 11:29 \\
\hline IV & 3 & 122,769797 & $-4,476427$ & 8,15 & 4,3 & 41,2 & 30,4 & $11: 20$ \\
\hline IV & 4 & 122,767034 & $-4,470642$ & 8,05 & 4,5 & 41,5 & 30,8 & $11: 12$ \\
\hline \multicolumn{4}{|c|}{ Rata-Rata } & 8,2 & 4,4 & 41,3 & 30,6 & - \\
\hline
\end{tabular}


Media Akuatika : Jurnal Ilmiah Jurusan Budidaya Perairan. 2020. 5(3): 115-128.

Tabel 4. Data hasil pengukuran $\mathrm{pH}$, Oksigen Terlarut, Suhu, dan Salinitas Tahap 4

\begin{tabular}{|c|c|c|c|c|c|c|c|c|}
\hline \multirow{2}{*}{ St. } & \multirow{2}{*}{ Plot } & \multicolumn{2}{|c|}{ Koordinat } & \multirow{2}{*}{ pH } & \multirow{2}{*}{$\begin{array}{c}\text { DO } \\
(\mathrm{mg} / \mathrm{l})\end{array}$} & \multirow{2}{*}{$\begin{array}{c}\text { Suhu } \\
{ }^{\circ} \mathbf{C}\end{array}$} & \multirow{2}{*}{$\begin{array}{c}\text { Salinitas } \\
\text { (ppt) }\end{array}$} & \multirow{2}{*}{$\begin{array}{c}\text { Waktu } \\
\text { (WITA) }\end{array}$} \\
\hline & & Bujur & Lintang & & & & & \\
\hline I & 1 & 122,61288 & $-4,421777$ & 8,29 & 6,8 & 31,6 & 41,2 & $18: 32$ \\
\hline I & 2 & 122,627087 & $-4,432704$ & 8,22 & 6,3 & 31,5 & 41,2 & $18: 59$ \\
\hline I & 3 & 122,635186 & $-4,449414$ & 8,24 & 6,7 & 31,1 & 41,1 & 19:27 \\
\hline I & 4 & 122,647119 & $-4,454135$ & 8,22 & 6,8 & 31 & 41,1 & 19:43 \\
\hline \multicolumn{4}{|c|}{ Rata-Rata } & 8,24 & 6,65 & 31,3 & 41,15 & - \\
\hline II & 1 & 122,65953 & $-4,480827$ & 8,22 & 7,5 & 31,2 & 41,1 & $22 ; 12$ \\
\hline II & 2 & 122,660786 & $-4,486577$ & 8,24 & 7,3 & 31 & 41,1 & $22: 26$ \\
\hline II & 3 & 122,663042 & $-4,49253$ & 8,26 & 7,5 & 31,1 & 41,1 & $22: 38$ \\
\hline II & 4 & 122,663052 & $-4,496799$ & 8,28 & 7,1 & 31 & 41,1 & 23:00 \\
\hline \multicolumn{4}{|c|}{ Rata-Rata } & 8,25 & 7,35 & 31,08 & 41,1 & - \\
\hline III & 1 & 122,611754 & $-4,451262$ & 8,12 & 7,1 & 30,9 & 41,1 & $20: 04$ \\
\hline III & 2 & 122,607228 & $-4,463967$ & 8,2 & 7,5 & 30,9 & 41,1 & $20: 16$ \\
\hline III & 3 & 122,620627 & $-4,468827$ & 8,17 & 7,8 & 30,9 & 41,2 & $20: 28$ \\
\hline III & 4 & 122,622415 & $-4,479393$ & 8,2 & 7,7 & 30,9 & 41,2 & $20: 40$ \\
\hline \multicolumn{4}{|c|}{ Rata-Rata } & 8,17 & 7,53 & 30,9 & 41,15 & - \\
\hline IV & 1 & 122,772881 & $-4,493261$ & 8,17 & 7,5 & 30 & 41,1 & $0: 04$ \\
\hline IV & 2 & 122,775308 & $-4,486902$ & 8,5 & 7,6 & 30 & 41,1 & $0: 23$ \\
\hline IV & 3 & 122,776698 & $-4,479393$ & 8,1 & 7,3 & 30 & 41,1 & $0: 41$ \\
\hline IV & 4 & 122,777142 & $-4,471613$ & 8,1 & 7,5 & 30 & 41,1 & $0: 52$ \\
\hline \multicolumn{4}{|c|}{ Rata-Rata } & 8,22 & 7,48 & 30 & 41,1 & - \\
\hline $\mathrm{I}$ & 1 & 122,61288 & $-4,421777$ & 8,13 & 6,8 & 30,4 & 41,13 & $6: 33$ \\
\hline I & 2 & 122,627087 & $-4,432704$ & 8,16 & 6,8 & 30,4 & 39,45 & $6: 59$ \\
\hline $\mathrm{I}$ & 3 & 122,635186 & $-4,449414$ & 8,16 & 7,5 & 30,4 & 41,00 & $7: 29$ \\
\hline I & 4 & 122,647119 & $-4,454135$ & 8,13 & 7,5 & 30,4 & 39,60 & $7: 50$ \\
\hline \multicolumn{4}{|c|}{ Rata-Rata } & 8,15 & 7,15 & 30,4 & 40,29 & - \\
\hline II & 1 & 122,65953 & $-4,480827$ & 8,18 & 7,5 & 30,8 & 41,1 & 10:11 \\
\hline II & 2 & 122,660786 & $-4,486577$ & 8,14 & 7,2 & 30,8 & 41,1 & $10: 26$ \\
\hline II & 3 & 122,663042 & $-4,49253$ & 8,13 & 7,2 & 30,8 & 41,2 & $10: 40$ \\
\hline II & 4 & 122,663052 & $-4,496799$ & 8,23 & 7,6 & 30,8 & 41,2 & 11:05 \\
\hline \multicolumn{4}{|c|}{ Rata-Rata } & 8,17 & 7,37 & 30,8 & 41,15 & - \\
\hline III & 1 & 122,611754 & $-4,451262$ & 8,13 & 7,2 & 30,8 & 41,1 & $8: 03$ \\
\hline III & 2 & 122,607228 & $-4,463967$ & 8,13 & 7,6 & 30,8 & 41,1 & $8: 19$ \\
\hline III & 3 & 122,620627 & $-4,468827$ & 8,14 & 7,7 & 30,8 & 41,1 & $8: 30$ \\
\hline III & 4 & 122,622415 & $-4,479393$ & 8,2 & 7,6 & 30,8 & 41,1 & $8: 50$ \\
\hline \multicolumn{4}{|c|}{ Rata-Rata } & 8,15 & 7,5 & 30,8 & 41,1 & - \\
\hline IV & 1 & 122,772881 & $-4,493261$ & 8,2 & 6,1 & 30,4 & 41,1 & 12:00 \\
\hline IV & 2 & 122,775308 & $-4,486902$ & 8,14 & 6,4 & 30,4 & 41,1 & $12: 33$ \\
\hline IV & 3 & 122,776698 & $-4,479393$ & 8,16 & 6,8 & 30,4 & 41,1 & $12: 43$ \\
\hline IV & 4 & 122,777142 & $-4,471613$ & 8,15 & 4,8 & 30,5 & 41,1 & $12: 54$ \\
\hline \multicolumn{4}{|c|}{ Rata-Rata } & 8,16 & 6,0 & 30,4 & 41,1 & - \\
\hline
\end{tabular}




\section{PEMBAHASAN}

Derajat keasaman perairan $(\mathrm{pH})$ yaitu tingkat kosentrasi ion hidrogen $\mathrm{H}^{+}$atau proton yang terkandung dalam air. $\mathrm{pH}$ air ini biasanya tidak merupakan ancaman yang langsung bagi udang vaname di tambak. Derajat keasaman selama penelitian berkisar 7,44 hingga 8,3 menunjukkan bahwa perairan laut kecamatan Lainea kabupaten Konawe Selatan cenderung basah atau kosentrasi $\mathrm{OH}^{-}$meninggi. Perbedaan nilai $\mathrm{pH}$ disetiap stasiun dan spot penelitian diduga adanya perbedaan waktu pengukuran. Perubahan kosentrasi $\mathrm{pH}$ perairan mempunyai siklus harian. Siklus tersebut sebagai fungsi dari karbondioksida bebas dan ion karbonat maka $\mathrm{pH}$ akan cenderung asam atau $<7$. $\mathrm{pH}$ mempengaruhi proses dan kecepatan reaksi kimia di dalam air media maupun reaksi biokimia dalam tubuh udang vaname, mempengaruhi daya racun suatu senyawaa, kelangsungan hidup dan pertumbuhan udang vaname. Menurut Chamberlain (1988) Tingkat pH kolom air laut berfluktuasi sesuai dengan keadaan fotosintesis dan pernafasan yang sedang terjadi, yaitu mulai dari angka rendah pada waktu fajar hingga matahari tinggi pada pertengahan sore hari. Hasil pengukuran $\mathrm{pH}$ yang berkisar 7,44-8,30 menunjukan bahwa perairan tersebut layak untuk dijadikan sumber air pengairan tambak super intensiv.

Kandungan oksigen air laut selama penelitian 4,40 $\mathrm{mg} /$ liter hingga 12,7 $\mathrm{mg} /$ liter. Oksigen terlarut atau biasa disebut disolved oxygen biasa diukur dalam $\mathrm{mg} / \mathrm{l}$ atau bagian per satu juta (ppm). Kosentrasi oksigen terlarut yaitu jumlah kandungan $\mathrm{O} 2$ dalam setiap liter air laut pada tempat dan waktu tertentu. Oksigen dibutuhkan oleh semua jasad hidup untuk pernapasan, proses metabolisme atau pertukaran zat yang kemudian menghasilkan energi untuk pertumbuhan dan pembiakan. Disamping itu, oksigen juga dibutuhkan untuk oksidasi bahan-bahan organik dan anorganik dalam proses aerobik. Sumber utama oksigen dalam suatu perairan berasal sari suatu proses difusi dari udara bebas dan hasil fotosintesis tumbuhan yang hidup dalam perairan tersebut. Kecepatan difusi oksigen dari udara, tergantung sari beberapa faktor, seperti kekeruhan air, suhu, salinitas, pergerakan massa air dan udara seperti arus, gelombang dan pasang surut.

Salmi (2005) menyatakan bahwa kandungan oksigen terlarut dalam perairan yang baik untuk pertumbuhan hewan air yaitu $>5$ ppm. Menurut Atjo (2013) kandungan oksigen terlarut pada budidaya udang vaname teknologi superintensiv berkisar antara 6,0-12 ppm, tergantung jumlah tebar. Kebutuhan oksigen terlarut oleh udang vaname melalui proses pernapasan digunakan untuk metabolisme karbohidrat, protein, dan lemak pakan yang dikonsumsi untuk menghasil energi. Energi digunakan untuk pertumbuhan, maintenance, melawan perubahan lingkungan yang ekstrim. Oksigen terlarut juga dimanfaatkan bakteri probiotik memanfaatkan bahan organik dan proses pembelahan sel. Kandungan oksigen terlarut air hasil penelitian ini lebih tinggi dibanding data DO perairan tambak Dinas Kelautan dan Perikanan Kabupaten Konawe Selatan (2016) sebesar 5,40 mg/ liter hingga 6,850 $\mathrm{mg} /$ liter. Lebih rendah karena tingkat pemanfaatan sangat tinggi oleh ikan bandeng dan udang vaname.

Salinitas atau kadar garma merupakan hasil reaksi senyawa asam dan senyawa basa. Salinitas disefinisikan sebagai jumlah semua garam dalam air setelah semua karbonat dirubah menjadi oksida-oksidanya, semua Bromida dan Iodida digantikan oleh Chlorida dan dinyatakan dalam satuan perseribu. Salinitas membedakan jenis air menjadi air laut, air payau, dan air tawar. Udang vaname tergolong udang yang mampu hidup dan tumbuh pada kondisi eurihalin. Menurut Dirjen Perikanan Budidaya (2018) udang vaname tumbuh dengan baik pada kisaran salinitas 20-30 ppt.

Kisaran salinitas air laut selama penelitian yaitu 31,3-41,3 ppt masih cukup tinggi karena bulan Oktober dan November merupakan puncak musim kemarau terjadi pemanasan air yang tinggi. Kondisi salinitas perairan yang tinggi di kolam tandon dan dalam petakan tambak dapat diturunkan dengan menambahkan air tawar. Menurut MAI (2017) dan ISW.co.id (2018) udang vaname dapat tumbuh secara optimum 
salinitas berkisar $15-25 \mathrm{ppt}$, sedangkan udang windu 20-25 ppt. Menurut Direktorat Jenderal Perikanan Budidaya (2018) bawa udang vaname dapat dibudidayakan pada salinitas tinggi berkisar 38-40 ppt dengan kelangsungan hidup 82,66\%. Selanjutnya menurut Balubi (2017) larva dan benih udang vaname dapat tumbuh dengan baik di hatchery pada salinitas 29-30 ppt. Sedangkan menurut Permen KP No. 75 (2016), salinitas tambak untuk budidaya udang vaname super intensif berkisar 26-32 ppt.

Kadar nitrat (NO3) di perairan tambak merupakan nutrien utama sebagai hasil oksidasi yang bermanfaat bagi pertumbuhan alga dan kelekap. Proses terbentuknya nitrat dalam perairan merupakan hasil reaksi oksidasi dari senyawa nitrit (NO2) melalui bantuan bakteri Nitrobacter. Nitrit sendiri berasalal dari hasil reaksi oksidasi amonia (NH3) dengan bantuan bakteri Nitrisomonas. Kehadiran amonia dan nitrit dalam tambak pada kosentrasi tertentu dapat bersifat toksit yang dapat menghambat pertumbuhan udang vaname di tambak. Kandungan nitrit yang tinggi disebabkan tidak seimbangnya kecepatan reaksi perubahan dari nitrit menjadi nitrat.

Berdasarkan hasil analisis kadar nitrat air tambak kecamatan Lainea kabupaten Konawe Selatan selama penelitian yaitu berkisar $0,0544 \mathrm{mg} / 1$ hingga $0,0881 \mathrm{mg} / \mathrm{l}$. Dalam kegiatan operasional tambak super intensiv alga diperlukan sebagai peneduh udang dari terik matahari dan peredam dari senyawa berbahaya bagi udang vaname. Alga bukan sebagai pakan, karena kebutuhan nutrisi untuk kehidupan dan pertumbuhan udang vaname sepenuhnya dipenuhi dari pakan buatan yang diberikan secara rutin. Kandungan nitrat tersebut masih dalam kondisiyang ideal bagi pertumbuhan alga laut. Hasil penelitian ini lebih rendah dibanding hasil penelitian Pasongli dkk. (2015) mengatakan bahwa kandungan nitrat $0,1955-1,405 \mathrm{mg} /$ liter dinyatakan keadaan tambak udang vaname masih sangat sesuai. Kandungan nitrat di tambak udang super intensiv dapat meningkat seiring dengan tingkat sisa-sisa pakan dan hasil metabolit udang vaname selama kegiatan pembesaran.

Phospat di tambak bersumber dari berbagai lapukan bahan organik, batuan, lapukan mangrove, dan PO4 dalam tanah. Zat phospor sangat penting untuk menyusun protein dan membantu dalam proses respirasi. Keadaannya di dalam air akan terurai menjadi senyawa ionisasi antara lain dalam bentuk ion $\mathrm{H}_{2} \mathrm{PO}_{4}$, $\mathrm{HPO}^{2-}, \mathrm{HPO}^{3-}$. Phospat diabsorpsi oleh alga dan seterusnya masuk dalam rantai makanan.

Kandungan phospat air tambak selama penelitian berkisar antara 0,0053 hingga $0,0093 \mathrm{mg} /$ liter. Kadar phospat air tambak ini masih dalam kondisi yang baik untuk pengembangan tambak super intensif. Jika phospat dalam air tambak terlalu tinggi akan berbahaya karena dapat menimbulkan bloming phitoplankton yang berakibat pada rektide. Pembusukan phitoplankton dimalam hari akan berakibat pada defisiensi oksigen, sehingga udang vaname kekurangan oksigen. Kekurangan oksigen ini menyebabkan udang kerdil, jika sangat kurang maka udang vaname bisa mati.

Amonia (NH3-N) dalam air tambak bersifat racun jika dalam jumlah banyak dapat menimbulkan kematian. Amonia sebahagian besar pada tambak intensif bersumber dari sisa metabolisme protein. Penumpukan sisa-sisa pakan dalam reaksi oksidasi berubah menjadi amonia. Dalam industri akuakultur tambak udang vaname super intensif sisa metabolisme pakan ini akan diurai oleh bakteri batang sebagai probiotik. Bakteri probiotik dikultur secara masal sesuai kebutuhan, selanjutnya ditebar di tambak udang vaname, untuk mengurai sisa-sisa pakan tersebut sekaligus melawan bakteri patogen seperti jenis Vibrio harvey. Probiotik ini juga dapat mencegah masuknya penyakit lain yang bersumber dari protozoa dan jamur.

Kandungan amonia selama penelitian rata-rata berkisar $0,0101 \mathrm{mg} /$ liter hingga $0,0239 \mathrm{mg} /$ liter. Kosentrasi amonia tersebut masih dalam kondisi aman bagi pertumbuhan dan derajat kehidupan udang vaname.

Air tambak banyak mengandung bahan organik sebagai hasil dari proses biologi, kimia, dan fisika perairan yang 
berlangsung secara alamia. Organisme yang mati baik hewan maupun tumbuhan mengalami proses kimiawi dan fisika hingga terjadi penguraian dari senyawa kompleks menjadi senyawa sederhana. Senyawa sederhana ini akan larut dalam air dan masuk ke semua kolom air termasuk di tambak. Kosentrasi bahan organik yang tinggi akan mengganggu proses fisiologi udang vaname, sehingga diperlukan penanganan mutu air yang tepat. Bahan organik air tambak selama penelitian berkisar antara $16,620 \mathrm{mg} /$ liter hingga $27,625 \mathrm{mg} /$ liter. Kondisi masih sesuai dengan kriteria bahan organik air media budidaya udang vaname yang dianjurkan. Dijelaskan oleh Pirzan dan Mustafa (2011) bahwa kandungan bahan organik di tambak udang danikan berkisar antara 13,27 hingga $37,92 \mathrm{mg} /$ liter baik untuk pertumbuhan dan kelangsungan hidup. Menurut Peraturan Menteri Kelautan dan Perikanan RI No. 75 (2016) bahwa kandungan bahan organik air tambak $\leq 90 \mathrm{mg} /$ liter.

\section{KESIMPULAN}

Berdasarkan hasil penelitian dapat disimpulkan bahwa kualitas hidrologi perairan laut dengan $\mathrm{pH} 7,44-8,30$, DO 4,40-12,7 mg/ liter dan salinitas air laut 31,3-41,3 ppt, masih dalam keadaan layak bagi industri tambak superintensif udang vaname. Dan untuk kesuburan air tambak selama penelitian yaitu kosentrasi nitrat 0,0544-0,0881 $\mathrm{mg} /$ liter, phospat 0,0053 $0,0093 \mathrm{mg} /$ liter, amonia $0,0101-0,0239$ $\mathrm{mg} /$ liter, dan bahan organik 16,620-27,625 $\mathrm{mg} /$ liter merupakan kondisi yang baik untuk budidaya udang vaname super intensif.

\section{UCAPAN TERIMA KASIH}

Terimakasih yang sebesar-besarnya kepada Lembaga Penelitian dan Pengbadian Masyarakat Universitas Halu Oleo (LPPMUHO) dan Dinas Kelautan Perikanan Kabupaten Konawe Selatan (DKP-Kab. Konawe Selatan) atas perkenaannya membantu dan memfasilitasi seluruh kebutuhan tim peneliti (penulis) serta tim survey Hidro-Oseanografi selama melakukan kegiatan penelitian mengenai studi parameter fisika-kimia perairan pada kawasan rencana pengembangan tambak super-intensif udang vaname (Litopenaeus vanamei) di Kabupaten Konawe Selatan.

\section{REFERENSI}

Atjo, H. (2013). Budidaya Udang Vaname Supra-intensif Indonesia. Dipresentasikan pada Launching Budidaya Udang Vaname Suppraintensif. MAI-SCI Sulawesi Selatan.

Balubi, A. M. (2017). Pembenihan Udang Windu (Penaeus monodon Fab.) dan UdangVaname (Litopenaeus vannamei ). Bahan Ajar Manajemen Pembenihan. Fakultas Perikanan dan Ilmu Kelautan Universitas Halu Oleo. Kendari.

Chamberlain, W. G. (1988). Tinjauan kembali Pengelolaan Tambak Udang, dalam Prinsip Pengelolaan Budidaya Udang. Technical Bulletin.

Dinas Kelautan dan Perikanan Kabupaten Konawe Selatan. (2016). Inventarisasi dan Pemetaan Lahan Tambak dan Kolam Ikan Air Tawar Kabupaten Konawe Selatan.

Dirjen Perikanan Budidaya. (2018). Desain Konstruksi Budidaya Tambak. Rancang Bangung Akuakultur, Jalan Merdeka Timur, Jakarta.

ISW.co.id. (2018). Ilmu Pengetahuan Info Budidaya Ikan Vol. 28. Blog.

MAI. (2017). Bagaimana Penaeus vannamei Mengatasi Air Salinitas Rendah. Ilmiah Populer, Info Teknologi, Jakarta.

Pirzan, A. M dan A. Mustafa. (2011). Hubungan antara Kualitas Air dan Kandungan Klorofil-a di Tambak Kabupaten Mamuju Provinsi Sulawesi Barat. Balai Riset Perikanan Budidaya Air Payau, Maros.

Salmi. (2005). Oksigen Terlarut (DO) dan Kebutuhan Oksigen Biologi (BOD) sebagai salah satu Indikator untuk menentukan Kualitas Perairan. Oseana, Volume XXX, No. 3, hal. 21-26. Oseana, Volume XXX, Nomor 3, $2005: 21-26$.

Pasongli H., Gufran D. Dirwan, dan Suprapta, 2015. Zonasi Kesesuaian Tambak untuk Pengembangan Budidaya Udang Vaname (Penaeus 
vannamei) pada Aspek Kualitas Air di Desa Todowongi Kecamatan Jailolo Kabupaten Halmahera Barat. Jurnal Bioedukasi ISSN : 2302-4678 Vol 3 No (2) Maret 2015.

Standar Nasional Indonesia (SNI). (2004). Air dan air limbah - Bagian 22: Cara uji nilai permanganat secara titrimetri.

Standar Nasional Indonesia (SNI). (2005).

Cara Uji Kadar Amonia (NH3) dengan Metode Indofenol menggunakan Spektrofotometer.

Standar Nasional Indonesia (SNI). (2011). Cara Uji Nitrat (NO3-N) dengan Spektrofotometer UV-visibel secara Reduksi Kadmium (Cd). 